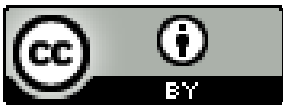

\title{
GANHADEIRAS: TRABALHO FEMININO NAS RUAS DO RECIFE SETECENTISTA
}

\author{
Suely Creusa Cordeiro de Almeida ${ }^{1}$
}

Resumo: Este artigo trata das ações desenvolvidas pelas mulheres negras escravizadas e que praticaram o comércio de rua na cidade do Recife na segunda metade do século XVIII. Nós constatamos que o sucesso dessas mulheres não se baseava simplesmente em seus relacionamentos com aliados de camadas sociais mais baixas, mas também com as irmandades negras, com seus senhores que provavelmente eram comerciantes estabelecidos no comércio de Recife, funcionários do conselho municipal, autoridades do reino e governadores da capitania que pudessem conferir as Patentes Negras, um documento que lhes permitia exercer uma profissão legalizada.

Palavras-chave: escravidão, protagonismo feminino, trabalho feminino

\section{GANHADEIRAS: WOMEN'S WORK ON THE STREETS OF RECIFE IN THE 18TH CENTURY}

Abstract: This work deals with the actions developed by enslaved black women who carried out street commerce in the city of Recife in the second half of the 18th century. We approach their successes based on their relations with allies who were of lower social levels, but also with the black brotherhoods, and with their masters who were probably traders established in the commercial square of Recife, components of the City Council and Kingdom authorities as the governors of the captaincy that could confer the Black Patents, document that allowed to carry out a legalized trade.

Keyword: slavery, female protagonism, female work

\footnotetext{
${ }^{1}$ Suely Creusa Cordeiro de Almeida graduou-se em História na Universidade Católica de Pernambuco. Obteve o grau de mestre, com o estudo “A Companhia de Navegação Pernambucana Costeira por Vapor". Doutorou-se em História pela Universidade Federal de Pernambuco, com bolsa sanduíche ligada a Universidade Clássica de Lisboa em 2003, com a tese O Sexo Devoto: normatização e resistência feminina no Império Português XVI -XVIII publicada, em 2005, pela Editora Universitária da UFPE. Em 2009 cumpriu o estágio Pós-Doutoral junto ao professor Antonio Manuel Hespanha na Universidade Nova de Lisboa. Integra o corpo docente da Graduação e Pós-Graduação do Curso de História da Universidade Federal Rural de Pernambuco e da Pós-Graduação em História da Universidade Federal de Pernambuco. É autora de artigos e livros. E-mail: suealmeida.ufrpe@ hotmail.com
}

Revista da ABPN • v. 12, n. Ed. Especial - Caderno Temático: "Africanos, escravizados, libertos biografias, imagens e experiências atlânticas" • agosto de 2020, p. $52-70$ 


\section{GANADORES: TRABAJO FEMENINO EN LAS CALLES DE RECIFE SIGLO XVIII}

Resumen: Este trabajo trata de las acciones desarrolladas por mujeres negras esclavizadas que llevaron a cabo el comercio callejero en la ciudad de Recife en la segunda mitad del siglo XVIII. Nos acercamos a sus éxitos en función de sus relaciones con aliados que provienen de estratos sociales subordinados, pero también con las hermandades negras y con sus amos que probablemente eran comerciantes establecidos en la plaza comercial de Recife, componentes del personal del Ayuntamiento y autoridades del reino como Los gobernadores de la capitanía que podían conferir las Patentes Negras, un documento que les permitía llevar a cabo un comercio legalizado.

Palabra clave: esclavitud, protagonismo femenino, trabajo femenino

\section{GANHADEIRAS: LE TRAVAIL FÉMININ DANS LES RUES DE RECIFE AU XVIIIE SIÈCLE}

Résumé: Cet article porte sur les actions développées par des femmes noires réduites en esclavage et qui exerçaient le commerce de rue dans la ville de Recife dans la seconde moitié du XVIIIe siècle. Nous constatons que le succès de ces femmes-là n'était pas simplesmente en fonction de leurs rapports avec des alliés issus de couches sociales subalternes, mais aussi avec les confréries noires, avec leurs maîtres qui étaient probablement des marchands établis dans le commerce de Recife, du personnel du conseil municipal, des autorités du royaume et les gouverneurs des capitaineries qui pouvaient conférer les Brevets Noirs, document qui leur permettait d'exercer un métier légalisé.

Mot-clé: esclavage, protagonisme féminin, travail féminin

\section{INTRODUÇÃO}

As cidades atlânticas setecentistas e seus portos foram marcadas/os pela presença de gente de múltiplas qualidades e variados tons de pele. Acrescente-se a presença de uma população escrava, em grande medida feminina, trabalhadoras de ribeiras, quitandas, mercados e ruas e praças. Elas buscavam garantir a sobrevivência, comprar alforrias, amealhar jornais para seus senhores, mas, em seu trabalho diário e árduo, acabaram garantindo o abastecimento de cidades às margens do Atlântico e viabilizando o comércio costeiro, como no caso da cidade do Recife.

Revista da ABPN • v. 12, n. Ed. Especial - Caderno Temático: "Africanos, escravizados, libertos biografias, imagens e experiências atlânticas” • agosto de 2020, 
Um enxame! Termo que define o pulular de mulheres de cor nas ruas do Recife, cidade negreira e que, ao sabor do ritmo do pequeno comércio, "de portas a fora", agenciavam a sobrevivência. Gritavam a todos os pulmões sob as janelas oferecendo suas mercadorias à venda. Era um vozerio mesclado em todos os tons e semitons possíveis a seres humanos! Bananas, laranjas, doces e mais uma infinidade de produtos, que por ventura uma pessoa pudesse necessitar (KOSTER, 1978, p. 29). Todo o aparato legal que envolvia o contingente de mulheres brancas e livres as deixava de fora, para elas não havia proteção; elas eram em sua maioria escravas, mas, mesmo as livres de cor, estavam colocadas tão abaixo na pirâmide social colonial que seus destinos não interferiam em nada na ordem superior das coisas (ORDENAÇÕES FILIPINAS, 1985, L. 5). A presença das negras nas ruas foi descrita por Henry Koster (1978) de modo melancólico: "sua presença dava as ruas um aspecto sombrio", pois segundo o viajante inglês, as mulheres portuguesas e brasileiras, mesmo as mulatas de estrato médio, não chegavam à porta de casa durante o dia, assistindo missa ainda pela madrugada, entrando na igreja de cabeça coberta, saindo para passeios protegidas pelo palanquim e só ocasionalmente à tarde a pé junto com toda a família (KOSTER, 1978, p. 31). Assim a urbe era povoada por mulheres negras e seus afazerem de trabalhadoras, criando uma paleta de cores feminina monocromática nos bairros centrais do Recife.

As trabalhadoras, em sua maioria, agenciavam "à dias" e eram lavadeiras, costureiras, cozinheiras, amas, copeiras, regateiras, ganhadeiras, boceteiras, pombeiras, quitandeiras, frissureiras, fiadeiras, cacheteiras, marisquiras e prostitutas, vendiam tudo até o corpo (BLUTEAU, 1728, v. 8, p. 138, 588). Os pontos de venda estavam espalhados pelo bairro do porto do Recife, Ilha de Santo Antônio e Boa Vista; mas também às margens e ao longo do rio Capibaribe, lá estavam as ganhadeiras, esperando os canoeiros com suas frutas, bolos e doces e eles, os canoeiros,_sem perda de tempo, compravam os seus produtos, e com elas faziam as trocas de interesses mútuos (KOSTER, 1978, p. 38).

Os momentos que propiciavam o aumento das vendas não eram desprezados por essas agenciadoras, como, por exemplo, o fim do jejum quaresmal que antecede a Páscoa. Esse se dava no sábado logo em seguida a sexta-feira Santa, quando, logo cedo,

Revista da ABPN • v. 12, n. Ed. Especial - Caderno Temático: "Africanos, escravizados, libertos biografias, imagens e experiências atlânticas" • agosto de 2020, p. $52-70$ 
um grande grupo de mulheres negras saiam às ruas com cestos contendo galinhas e perus, arrastando porcos e tudo o mais que pudesse transformar-se em uma bela refeição (KOSTER, 1978, p. 43).

Mas, o que significava cada termo atribuído a essas mulheres no mundo do trabalho e o que nos esclarece os dicionários de época? O termo pombeiro é verbete em três dicionários: Raphael Bluteau (1728), Antonio de Morais Silva (1813) e Luis Maria da Silva Pinto (1832). Segundo Bluteau, o termo pombeiro aparece no masculino e faz referência aos escravos nascidos em cativeiro dos portugueses na África. Eles estavam quase o ano todo longe da casa de seu senhor, ocupados em comprar escravos, marfim, cobre e outras mercadorias. O dicionarista Morais Silva repete a definição de Bluteau, mas acrescenta "o que vende peixe nas ribeiras e parte os lucros com seu senhor" (1813, p. 466). Luis Maria da Silva Pinto (1832) compila Morais Silva (1813). Pereira da Costa (1976) em seu "Vocabulário Pernambucano" também se refere ao termo como vendedor ou vendedora de peixe. Assim, concluímos que pombeira significava uma escrava ganhadeira que agenciava nas ruas do Recife dividindo os rendimentos com seu senhor nos negócios do pescado. Elas podiam esperar os jangadeiros ou tarrafeadores na praia e ali negociarem a venda do pescado como atravessadoras. É inferível que tinham autonomia para realizarem as negociações, inclusive tornando-se especialistas em escolher o produto. Esse cenário não era privilégio da Capitania de Pernambuco, mas uma realidade para as conquistas portuguesas atlânticas como já demonstrou a historiografia.

Quanto ao termo boceteira não há referências nos dicionários citados, encontramos apenas boceta que tinha como um de seus significados o de pequeno vaso de qualquer matéria. Ou bocete como uma couraça de brocados ou a bocetes de malha. Mas, no "Vocabulário Pernambucano", Pereira da Costa (1976) define boceteira como uma mulher que se empregava no pequeno comércio, uma ambulante, vendedora de miudezas e rendas, produtos esses que eram acomodados em caixas ovais ou cilíndricas de madeira fina, com tampa, e vistosamente pintadas que tinham o nome vulgar de bocetas. O que nos leva a concluir que as boceteiras comercializavam variados produtos, podendo associar várias categorias em suas cestas, tabuleiros ou caixas, ou até

Revista da ABPN • v. 12, n. Ed. Especial - Caderno Temático: "Africanos, escravizados, libertos biografias, imagens e experiências atlânticas” • agosto de 2020, p. $52-70$ 
serem conhecidas por lidar com artigos mais delicados como adornos femininos para orelhas, pulsos, pescoço, dedos e cabelos, haja vista existir no Recife uma significativa produção de adornos em ouro incrustados com pedras semipreciosas, aos quais se refere Henry Koster (1978, p. 55) e os inventários setecentistas, especulação que nos permitem os textos e documentos citados (IAHGP - Testamento de Tereza Afonso/ Preta Forra 1768).

No Recife, no século XVIII, havia lugares onde era possível encontrar essas mulheres expondo seus produtos. Nas ruas em geral, abaixo das janelas, no entorno das vendas, lojas e tabernas, mas também às margens dos rios, elas abordavam os clientes e ofereciam a preços módicos os mesmos produtos que estavam nas prateleiras das lojas atraindo, com essa abordagem, a sanha colérica dos comerciantes de lojas abertas.

Para impedir a concorrência e normatizar a vida comercial citadina em Minas Gerais, Luciano Figueiredo (1998) demonstrou em O Avesso da Memória como a câmara, através de uma ação incisiva, passou a cobrar impostos dessas comerciantes do varejo para exporem seus produtos em tabuleiros e a organizá-las em um local específico das vilas e cidades mineiras.

Segundo Russell-Wood (2005), em Escravos e Libertos no Brasil Colonial, todo indivíduo de ascendência africana no Brasil estava subsumido às normas e regras estabelecidas por uma minoria branca. Para o comércio não foi diferente, pois as possibilidades de agenciamento estavam ligadas ao cumprimento das regras. Julga o historiador que a antipatia cerceava e restringia a participação desses indivíduos de cor no comércio por serem vistos como concorrentes e rivais. E embora considere que as medidas fiscais e jurídicas não fossem discriminatórias, muitas foram baixadas para coibir o que chamamos de ilegalidade do comércio que envolvia principalmente indivíduos mesclados ou negros, fossem escravos ou livres. No Recife, essa mercancia das negras cativas regateiras, que comercializavam fazendas secas em seus tabuleiros, levou ao Senado da Câmara, em 1743, a adotar uma postura que buscava coibir esse comércio considerado pernicioso para o povo, entenda-se, os mercadores de lojas. Os mercadores diziam que não havia condições esclarecer quais eram as roubadas das de legítimo pertencimento. Os mercadores arrazoavam que eram furtados continuamente

Revista da ABPN • v. 12, n. Ed. Especial - Caderno Temático: "Africanos, escravizados, libertos biografias, imagens e experiências atlânticas" • agosto de 2020 , p. $52-70$ 
em seus estabelecimentos. Não fica claro, como eram lesados, mas se pode deduzir, que havia uma rede de interessados que tanto poderiam surrupiar uma pequena quantidade dos produtos das lojas em momento de confusão no atendimento de muitos clientes durante o dia, como na calada da noite, sorrateiramente, e tudo levar sem serem vistos (AHU/PE- Cx.59, Doc. 5040).

É possível mensurar a rede articulada entre escravos, forros e brancos pobres, preocupados em garantir a própria sobrevivência e os expedientes de roubos, furtos e violências nas ruas, no porto, e nas casas comerciais. Um puxão, um solavanco, uma carreira e lá se ia um bem precioso; dobrando uma esquina ou sumindo em um beco sujo e escuro aonde encontrava a possibilidade de passar de mão em mão, e indo parar em cestas e tabuleiros de negras comerciantes ou fugindo em direção ao "fora de portas”, São José, lá pros lado dos Afogados, reduto de pobres, negros ou brancos, escravos fugidos ou de ganho, que viviam “dando nó em pingo d'água” para garantir o pão de cada dia. Esses furtos ou roubos encontravam caminho certo no comércio a retalho. Uma verdadeira "Feira da Ladra". 2

É claro que se esse clamor chegasse à Câmara e houvesse uma recorrência desse fato, poderia dar azoa um pedido de proibição de uma prática comum a todas as cidades e vilas da América portuguesa, que era o comércio ambulante feito por mulheres negras, fossem livres ou escravas. Mas, essa medida não agradaria a todos, principalmente aqueles que se valiam da estratégia de repassar seus produtos, no miudinho, de "porta em porta", esses sentir-se-iam prejudicados.

A presença de mulheres e homens de cor a negociarem nas ruas das urbes coloniais foi recorrente no Brasil setecentista. Em Minas Gerais, o conde de Assumar aprovou um édito, em 1719, que proibia que negros e negras forros possuíssem escravos ou lojas de alimentos. Essa medida foi revogada, mas Dom Lourenço de Almeida, governador em 1730, baixou para o distrito Diamantino uma proibição de edificação de lojas e tabernas por mestiços em um raio de duas léguas dos rios produtores de diamantes, medidas que foram acompanhadas de uma ação militar desempenhadas pelos

\footnotetext{
2 Teve origem na Idade Média, no século XIII. É o mais antigo mercado de Lisboa. Atualmente acontece no Campo de Santa Clara. Expõe-se todo tipo de artigos usados, e como o próprio nome denomina, as suas origens são de procedência incertas e não questionadas.
}

Revista da ABPN • v. 12, n. Ed. Especial - Caderno Temático: "Africanos, escravizados, libertos biografias, imagens e experiências atlânticas” • agosto de 2020, p. $52-70$ 
dragões. O distrito, apavorado com a truculência proveniente da Câmara, acaba informando que apenas algumas mulheres de cor forras misturaram-se aos escravos mineradores, informações que trouxeram à luz estratégias de mulheres para viabilizarem a mercancia, que era a de descer às áreas de mineração e repassarem comidas, bebidas e manufaturados, além das práticas de prostituição e, dali, retirarem o pagamento de seus serviços em ouro ou pedras preciosas desviadas dos donos de direito (RUSSEL-WOOD, 2005, p. 88 e 89).

Mas, no Recife o texto da postura da Câmara refere-se a quatro homens que, embora fazendo parte do Senado, recorreram ao Juiz de Fora, ${ }^{3}$ a maior autoridade administrativa representante do Rei na Câmara, pedindo que tornasse nula a postura que impedia o comércio das "negras regateiras", o que demonstra a pluralidade de interesses entre os comerciantes, bem como as hierarquias da mercancia no comércio da vila do Recife no século XVIII, que escalonava em ordem de importância homens de negócio e mercadores de loja aberta (ALMEIDA, 2007, p. 13 a 38). Ora, o que advogava o Senado da Câmara era que fossem proibidos de mercadejar negros e negras, mas havendo mercadores que desejassem mascatear o poderiam fazer livremente por seus caixeiros ${ }^{4}$ ou criados brancos, pessoas que não os faltava para esse mister (AHU/PE-Cx. 60, Doc. $5180)$.

Os homens bons ${ }^{5}$, de forma mordaz e para revidar, aproveitaram para criticar o comportamento do Juiz de Fora Presidente do Senado como um funcionário relapso que não frequentava as assembleias, "advogando segundo seus interesses e os de um grupo, que com semelhante comportamento demonstrava representar" (Registros e Provisões Bando (03.01.1769 -1797). É claro que acusações mais sérias ficavam subtendidas nesse libelo.

\footnotetext{
${ }^{3}$ Juiz de Fora: Magistrado profissional, que tinha com objetivo melhorar a administração da justiça e reduzir a parcialidade e o favoritismo da prática dos juízes ordinários, bem como a apropriação indébita de fundos por parte da Câmara. Tinha como responsabilidade realizar ações contra crimes e violências que ocorressem no termo de sua jurisdição.

${ }^{4}$ Caxeiro (com essa grafia) - BLUTEAU, Raphael, Op. Cit.,Significa o que guarda a caixa de dinheiro.

${ }^{5}$ Refere-se a uma elite administrativa, mercantil e agricultora da localidade.
}

Revista da ABPN • v. 12, n. Ed. Especial - Caderno Temático: "Africanos, escravizados, libertos biografias, imagens e experiências atlânticas" • agosto de 2020 , p. $52-70$ 
A câmara do Distrito Diamantino também defendeu empreendimentos da população de cor, advogando a útil contribuição aos fundos municipais através do pagamento de impostos. Dom Lourenço de Almeida fez ouvidos moucos acusando os vereadores de ligações sexuais com as mulheres de cor forras (RUSSEL-WOOD, 2005, p. 89). Não é impossível, que entre outras, essa também fosse uma acusação a uma parte da nobre vereança recifense.

O Senado do Recife quando teceu seu argumento, faz-nos perceber a luta internas, pois insistiu em que da Câmara participassem homens isentos dos interesses mercantis. Argumento que esclarece o quanto um novo extrato, enriquecido com o comércio de escravos, fazia pesar a balança econômica da capitania. Esses mercadores, através da Câmara, passaram a possuir o recurso de taxar os preços, bem como fiscalizar a execução das práticas comerciais na Praça recifense, gerando um monopólio que emanava de uma instituição legítima com representação da coroa, como a Câmara. Para garantirem seus intentos, buscaram manipular as eleições, escolhendo homens interessados em defender seus negócios, deixando ao largo os agricultores, que se sentiam impedidos por essas estratégias a alcançarem mandatos no Senado. Os homens bons, no intuito de banir da Câmara os comerciantes indesejáveis dão "nomes aos bois", denunciando a Basílio Rodrigues Seixas, Miguel Ferreira de Oliveira Gouvim, Chistovão de Freitas Guimaraens e Francisco de Oliveira, todos eles com comércio estabelecido em lojas, ou utilizando-se de caixeiros, componentes do Senado que advogavam, segundo a denúncia, em causa própria. Estava declarada a guerra contra o comércio nas ruas.

Já os quatro mercadores citados, aqueles que desejavam distanciar-se das acusações, buscavam asseverar ao Senado da Câmara, que não tinham ligações com esse comércio miúdo de rua e que também eram prejudicados pelo mesmo, demonstrando ser mais complexa a teia de interesses. Eles seguem na mesma cantilena, acusando as negras escravizadas de regateiras e ladras e que elas se aproveitavam da oportunidade de como escravas de ganho mesclar em seus cestos e tabuleiros as mercadorias de seus senhores, com as que por ventura fossem furtadas das casas de comércio e da Alfândega. Mas ainda estão nessa cena as mulheres casadas que furtavam

Revista da ABPN • v. 12, n. Ed. Especial - Caderno Temático: "Africanos, escravizados, libertos biografias, imagens e experiências atlânticas" • agosto de 2020 , p. $52-70$ 
fazendas dos maridos e associadas as suas escravas mandavam vendê-las nas ruas, há uma grande teia de relações articuladas (AHU/PE-Cx. 60, Doc. 5180). Elas também poderiam estar articuladas a intermediários, funcionários da Administração Colonial, e que tinha acesso aos artigos importados que chegavam ao Porto do Recife. Esses produtos, quer oriundos do monopólio ou resultado de um contrabando, passavam pelas mãos de vários personagens coniventes até chegarem às ruas da Vila do Recife. As articulações entabuladas por essas comerciantes de tabuleiro com funcionários subalternos da Coroa poderiam proporcionar acesso a artigos que alcançavam demanda nesse comércio a varejo, ora os azeites e os vinhos em tabuleiros são a maior preocupação dos senhores mercadores. Aqueles que tivessem o melhor argumento e o contato mais bem-sucedido sairiam na frente. Assim, era essencial para o comércio que as "pretas" repassassem as mercadorias em geral, os contrabandos e as fazendas estrangeiras concorrentes das de Portugal, comércio que não podia ser feito "às claras nos armazéns e lojas". Toda a mercadoria circulava sem pagar as devidas taxas. (ARAÚJO, 2007, p. 121).

A esse comércio refere-se um Bando do governador José Cezar de Menezes, já na segunda metade do século XVIII. O Bando de 1781 está diretamente ligado a Lei Pragmática de 1749, que não foi cumprida no momento de sua decretação e que visava proibir descaminhos comerciais. Esse contrabando, entrada ilícita de produtos de outros Estados na Praça do Recife, concorria fortemente com os produtos oriundos do monopólio, ou seja, os produtos portugueses que chegavam através dos barcos da Companhia de Comércio Pernambuco e Paraíba. Os Bandos deveriam ser fixados no Arco de Santo Antônio da Ponte e registrados na Secretaria do Governo e Câmara da vila (AHU/PE Cx. 90, Doc. 7232, 15/03/1759). Eis parte do texto documental:

\footnotetext{
Multiplicidade de volantes, mascates, marinheiros, pretos e pretas que pelas ruas públicas desta vila e seu subúrbios andam em [...] bocetas, tabuleiros, caixas e por outras diferentes formas vendendo ao povo toda qualidade de fazendas, e outros mais gêneros, e miudezas [...] Aquelas negras que publicamente trouxessem a cabeça as seguintes fazendas: panos brancos, botões da mesma espécie, linhos, agulhas, alfinetes (dedais), tesouras, fitas de lã, de linho e, (pentes), com tanto que todos estes gêneros sejam fabricados no Reino e seus domínios [...] (Registros e Provisões - Bando (03.01.1769 -1797).
} 
Dessa preocupação oficial podemos intuir que havia uma rede estruturada que burlava o controle fiscal da Alfândega do Porto do Recife. Talvez produtos ingleses, franceses ou do Oriente que, armazenados pelos negociantes de grosso trato, clandestinamente passassem para os tabuleiros e cestas de escravizadas agenciadoras a um preço menor de que os produtos oriundos do Reino. E concluía o governador sobre o dano que causavam a República e a "Real Fazenda na diminuição de seus direitos pelos contrabandos que vendem [...]" (APEJE-Registros e Provisões - Bando (03.01.1769 - 1797).

Por outro lado, vale ressaltar que os navios de Pernambuco transitavam por toda a costa brasileira em regime de cabotagem, ou até barcos menores enveredando rios adentro, realizando os mais variados negócios. Levando e trazendo produtos, comprando e vendendo, fossem produtos de interesse para o comércio com a África, consumo local ou para o abastecimento do próprio navio ou barco. Esse comércio feito pela cabotagem confundia e driblava o controle de circulação de produtos proibidos vindos do além-mar, limpando, lavando, esfumaçando o nome e o rosto dos infratores (AHU/PE- Cx. 82, Doc. 6867, 1756).

Pelas ruas eram vendidos todos os gêneros de produtos fossem de vara ou côvado, e também aqueles que não se configuravam de peso ou medida (FERREIRA, 1999). ${ }^{6}$ Os preços eram convidativos, pois ainda mais baratos do que se vendia em Portugal, ganhando a concorrência e arruinando aqueles que pagavam os impostos e estavam submetidos à fiscalização dos almotacés. Mas, como impedir semelhante prática? Os mercadores de lojas sugerem, como estratégia, que os escravos em geral, a eles só, seja permitido venderem gêneros comestíveis que, segundo os mercadores, eram oriundos do interior, "dos matos", produtos procedentes de pequenas lavouras nas franjas do açúcar ou de pequenos sítios, e que fosse proibida a venda dos produtos do reino por escravos ou até mesmo em casas particulares sob a pena de prisão e confisco

\footnotetext{
${ }^{6}$ Côvado: Antiga unidade de medida equivalente a três palmos. Vara: Unidade de medida equivalente a cinco palmos. FERREIRA, Aurélio Buarque de Holanda. Novo Aurélio século XXI: o dicionário de língua portuguesa. Rio de Janeiro: Nova Fronteira, 1999.
}

Revista da ABPN • v. 12, n. Ed. Especial - Caderno Temático: "Africanos, escravizados, libertos biografias, imagens e experiências atlânticas” • agosto de 2020, p. $52-70$ 
dos bens, tanto dos escravos como dos senhores (Livro de Registro da Câmara Municipal do Recife 1733-1808. p. 200v/201-203).

A posse de mercadorias que eram vendidas em tabuleiros ou em pequenos estabelecimentos como as mercearias ou taberna foi o tipo de negócio que mais proliferou entre a população livre de cor. Os registros municipais apontam que casais ou mulheres solteiras de cor nascidas livres ou forras chegaram a possuir esse tipo de estabelecimento, bem como ser proprietárias de escravos. Esse negócio não era especializado. Tanto nos tabuleiros como nas tabernas vendia-se de tudo: comida, bebida, roupas, pólvora, armas, ferramentas, utensílios domésticos, alguns artigos de luxo, como tecidos finos, jóias e coisas de toucador. Essas vendas ou tabernas se constituíram em espaços intermediários entre a legalidade e a ilegalidade, pois tais espaços esconderam escravos fugidos, abasteceram quilombos e viabilizaram a prostituição (RUSSEL-WOOD, 2005; FIGUEIREDO, 1993; CARVALHO, 2002).

Mas, o que apavorava a coroa era o contrabando e as negociatas que se realizavam fora do âmbito da Companhia de Comércio de Pernambuco e Paraíba ${ }^{7}$. Além do Bando de 1761, cartas insistem que os governadores da capitania atuassem intensivamente próximos às marinhas como forma de coibir a prática comercial ilegal (AHU/PE-Cx. 59, Doc. 5040). Os produtos não só entravam em Pernambuco clandestinamente pelas praias ou pelo Porto, mas eram enviados para a Bahia e Rio de Janeiro fugindo completamente do controle fiscal e dos oficiais da Companhia de Comércio de Pernambuco e Paraíba. Também os artigos do Sertão escapavam ao fisco, partindo das propriedades pelos rios para mercados e praças fora do Recife. A lista de produtos proibidos de serem embarcados para a Bahia e Rio de Janeiro eram: açúcar, couros, solas, tabaco, aguardente e Jeribita.

As recomendações para o Provedor da Alfândega eram no sentido de conferir os selos dos produtos que chagavam ao Porto do Recife, se vinham da Bahia, Rio de Janeiro ou do Reino, aguardar que as lojas apresentassem os referidos produtos no varejo para que imediatamente fossem novamente selados, ou seja, conferidos mais uma

\footnotetext{
7 A Companhia de Comércio Pernambuco e Paraíba foi fundada no reinado josefino com apoio de Marqueis de Pombal. Ela funcionou entre os anos de 1759 a 1780, e foi responsável pelo monopólio comercial que envolveu importações e exportação das Capitanias de Pernambuco e da Paraíba.
}

Revista da ABPN • v. 12, n. Ed. Especial - Caderno Temático: "Africanos, escravizados, libertos biografias, imagens e experiências atlânticas” • agosto de 2020, p. $52-70$ 
vez. Aqueles que fossem pegos com produtos que não passaram pelo primeiro crivo alfandegário receberiam as punições previstas pela lei de 08 de fevereiro de 1711, além do confisco da mercadoria, o pagamento das despesas com os soldados envolvidos nas diligências. Denúncias aos componentes da Mesa de Inspeção foram feitas no sentido de eles mesmos serem os responsáveis pela introdução das fazendas clandestinas, mas o governador afirma não ter tirado provas destas suspeitas (AHU/PE - Cx. 95. D. 7570, 04.09.1761; Cx. 99, D. 7757. 15.04.1763).

Nos momentos de crise de abastecimento, quando aportava um navio, chegou-se a pensar na venda de produtos diretamente a população, mas as formas de pagamento seriam de muita complexidade e exaustivas. O sortimento das lojas foi sempre a estratégia de opção, mas o que não se conseguia evitar era a especulação as compras a retalho. Os lojistas se utilizavam de variadas estratégias para alcançarem o maior volume possível de produtos, valendo-se de amigos e parentes que adquirissem pequenas porções desses artigos para depois lhes repassar, impedindo que todos os comerciantes pudessem ser supridos, além saírem na frente no que tange a oferta de produtos variados (AHU/PE-Cx.97, D. 7622, 09.12.1761). Assim, o trabalho das mulheres ganhadeiras era imprescindível para fazer com que a engrenagem dessa "roda da fortuna" girasse.

A grande maioria dos comerciantes de rua era composta por mulheres de cor. Elas equilibravam bandejas de doces e mais todo o tipo de alimento, fossem cozidos ou crus, com o objetivo de comercializá-los ganhando, assim, a subsistência. Para o exercício da tarefa era necessária a licença da Câmara Municipal, exigência que muitas vezes foi ignorada ou acordada com fiscais de plantão que, fazendo vista grossa, exigiam parte da receita das regateiras ou outros favores.

Houve um procedimento que fez surgir o "carambola" que era a prática de um produto passar por vários intermediários até chegar a seu destino final. Os soldados e oficiais subalternos funcionaram como esses intermediários, eles dirigiam-se aos locais onde os barcos aportavam no mar trazendo o pescado e, com a autoridade que possuíam, requisitavam esse produto com o argumento de que eram destinados aos seus superiores. Da mesma forma, essas autoridades subalternas invadiam os açougues,

Revista da ABPN • v. 12, n. Ed. Especial - Caderno Temático: "Africanos, escravizados, libertos biografias, imagens e experiências atlânticas” • agosto de 2020, p. $52-70$ 
tiravam as carcaças dos ganchos confiscando o produto de seus legítimos donos. O peixe era repassado para as amantes de cor desses soldados que o vendiam imediatamente. Já a carne, esta era preparada e cozinhada para ser vendida em pequenas porções. Essas damas eram chamadas de cacheteiras. A prática do confisco da carne gerava dificuldades em tempos de crise para a população conseguir comprar carnes frescas (VILHENA, 1922, p. 127 a 131).

Mas, as atividades de agenciar na rua não conferiam prestígio, pelo contrário, eram desonrosas. A rua não era lugar de mulher honrada, as que se arriscavam, o faziam por sua condição de pobreza, embora seu trabalho fosse fundamental para mover a engrenagem cotidiana da sociedade colonial. Em 1773 é ordenado no Recife que as "pretas" se retirassem das praças e passassem a vender junto às casas, mas essas ordens nunca foram obedecidas precisando para tal que houvesse uma real normatização da mercancia miúda, como ocorreu em Lisboa, Luanda ou em Minas Gerais (Câmara de Santo Antônio do Recife/Livro de Vereação-1764-1784, fls. 145 v e 146, 03/06/1773; ALMEIDA, 2013, p. 207). Só em 1788 são inauguradas as 62 casinhas da Praça da Polé, atual Praça da Independência, no centro da Vila do Recife, que foram construídas para serem arrematadas e depois alugadas para as "pretas" comerciantes, que nesse local poderiam vender hortaliças, frutas e cereais, o que demonstra que, com o trabalho, adquiriam pecúlio, e, embora mulheres e negras, adquiriram uma legitimidade para alugar imóveis. Assim organizadas, a cidade teria pela primeira vez um comércio com lugar definido para as ganhadeiras, pois, na forma anterior, era impossível cobrar impostos e punir os infratores (Câmara de Santo Antônio do Recife/Livro de Vereação (1785-1806, fls. 46) / 21/09/1788). Além da Praça da Polé, a Praça da Ribeira, atual Pátio do Mercado de São José, foi destinada para a venda de Peixes, no entanto, esse empreendimento levou anos em construção. Ainda na época de Tollenare, o comércio das ganhadeiras continuava concentrado na Praça da Polé. O viajante descreve o cenário onde as vendedoras de gêneros comestíveis passavam parte do dia, ou até esgotarem seus tabuleiros; algumas, às vezes, emendando o expediente com a mercancia de amores. O mercado que se posicionava junto da atual igreja do Convento de Nossa Senhora da Penha dos Frades Italianos Capuchinhos, oferecia um cenário em profusão 
de cores e formatos aonde se expunham raízes diversas e frutas: batatas, inhames e bananas, ananases, cajus, mangas e laranjas. Trajadas modestamente, as vendedoras eram um espetáculo à parte; elas exibiam um cachimbo ao queixo, enquanto preparavam manjares para os frequentadores (TOLLENARE, 1978, p. 21). Mas, mesmo sofrendo pressão para que se organizassem em determinados lugares elas, as ganhadeiras, continuaram transitando pelas ruas da cidade, gritando às portas e janelas as suas mercadorias, às vezes frutas, galinhas, cozidos, ou os mais variados produtos (KOSTER, 1978, p. 42-43).

As Governadoras das Boceteiras da Praça do Recife foram mulheres responsáveis na governabilidade das atividades comerciais, elas passaram a normatizar a comercialização de produto de um grande número de mulheres negras e mestiças que agenciavam nas ruas. Em junho de 1788, Bernarda Eugênia de Souza foi eleita "Governadora das Pretas Boceteiras e Comerciantes". Ela foi conduzida a ocupar esse lugar por suas colegas de atividade com o objetivo de manter a paz e o sossego do grupo. Grupo que cresceu consideravelmente em número e marcado pelas cores de mulheres alegres e empreendedoras, resultado de um Brasil mestiço com múltiplas caras e, ao mesmo tempo, eivado por animosidades, concorrências e ciúmes. Em meio ao burburinho das ruas e às adversidades de uma sociedade patriarcal, essas mulheres realizaram iniciativas organizacionais para se consolidarem numa atividade. Uma governadora deveria sofrer cobranças tantos de seus pares como das autoridades institucionalizadas, como o Governador da Capitania que, na época de Bernarda, era Dom Thomas José de Melo. Em Pernambuco, o documento que dava direito ao exercício dessas atividades foi chamado de "Patente Negra" (Patentes Provinciais v. 06 e 11 - Boceteiras e Comerciante; Pombeiras e Fora de Portas. 1788, 1789, 1802. p. 75, 263 e 267).

Governadora das Pombeiras, Reynalda Pinto de Carvalho assumiu a jurisdição da falecida Cristina Maria Luiza. Das mulheres era exigido:

Que cumpra inteiramente como deve sua obrigação do posto de governadora a boa confiança que fazemos dessa pessoa. [...] que exercerá enquanto proceder devidamente e que merecer ser nele conservada chegando o tempo de três anos

Revista da ABPN • v. 12, n. Ed. Especial - Caderno Temático: "Africanos, escravizados, libertos biografias, imagens e experiências atlânticas" • agosto de 2020 , p. $52-70$ 
(Patentes Provinciais v. 06 e 11 - Boceteiras e Comerciante; Pombeiras e Fora de Portas. 1788, 1789, 1802. p. 267).

Segundo a documentação depositada no fundo das Cartas Patentes, era o Governador da Capitania que nomeava uma "preta" para ser governadora de um grupo que exercia atividades na Praça do Recife, mas sempre houve pedidos dos "pretos forros”, independente de gênero (Patentes Provinciais - Cód. III, folha 92, 20.02.1778). E, embora o nome pudesse ser indicado, fosse pelas nações ou corporações e, até mesmo pelos homens de negócio ou pela Mesa de Inspeção, a autoridade para institucionalizar o cargo foi sempre do Governador da Capitania. Há de se observar que as hierarquias cimeiras entre os pretos nas irmandades, que iam do rei do congo aos governadores de nações, estavam em um patamar de subordinação a administração colonial fosse reinol ou local, no entanto, essas hierarquias das confrarias eram respeitadas. Elas faziam parte de um jogo de cena duma sociedade hierarquizada e ritualizada aonde cada instância tinha o seu papel e importância e, no que tange ao todo, se complementavam, pois cada um exercia e tinha um tipo de poder. Essa engrenagem incluía as irmandades e seus agentes como elos integrantes de um conjunto de ações promovidas pela administração da capitania. As governadoras, possuidoras das Patentes Negras, exerciam um papel de liderança e promoção da disciplina sobre as suas subordinadas. Fica evidente que essa elite negra de "pretas" que recebiam uma investidura de seu grupo, mas também das lideranças da capitania, já haviam alcançado uma redefinição de sua qualidade, às vezes através da mudança de sua condição, é claro entre as pessoas de cor. Ambos os grupos desse arranjo saem auferindo vantagem. A elite administrativa e proprietária de terras e escravizados, promoviam, pois, a organização, disciplina e controle sobre variados ofícios e afazeres mecânicos. Essa era uma característica da administração colonial portuguesa, que sempre repassou as responsabilidades pelo bem-estar social, garantindo o envolvimento de todos na política corporativista da coroa (RUSSEL-WOOD, 1998, v. 18, n. 36; HESPANHA e XAVIER, 1993, p. 123). A elite de cor construía para si um estado ou lugar social que, além de reproduzirem os rituais de prestígio da sociedade de corte (ELIAS, 2001, p. 24) frente a seus pares, promovia também a sua sobrevivência através da realização de seus ofícios,

Revista da ABPN • v. 12, n. Ed. Especial - Caderno Temático: "Africanos, escravizados, libertos biografias, imagens e experiências atlânticas” • agosto de 2020, p. $52-70$ 
enfatizando, inclusive, a sua importância frente ao corpo social como expressão de poder e prestígio para o grupo.

\section{CONSIDERAÇÕES FINAIS}

No Antigo Regime, não se considerava a rua como um lugar adequado para mulheres bem-nascidas, e muito menos um lugar que pudesse dignificar o trabalho manual. Tratar das mulheres comerciantes nas ruas das cidades, particularmente das cidades frutos das conquistas portuguesas, nos situa numa construção social de luzes e sombras, como observou Antônio Manuel Hespanha sobre o que era vulgar, desprezível e frágil, seguindo argumentos dos juristas do Reino e as Ordenações Filipinas (HESPANHA, 2010).

Já comandar um grupo de mulheres, para uma mulher negra forra significava inclusão, aceitação e visibilidade numa sociedade em que o fato de ser mulher era um óbice intransponível, desqualificação considerada inata. Por esse lugar de visibilidade, os indivíduos acabavam favorecendo a ordem, e intuímos, muitas vezes sem considerar a dimensão da importância de suas práticas. Assim instituía-se um jogo de escondeesconde entre as elites de cor e a elite administrativa lusas ou mazombas, todos manobrando o sistema com o fim de garantir seus interesses que iam da liberdade ao controle. Essa negociação nunca foi linear, pois muitos das/dos governadoras/dos das nações ${ }^{8}$ se insubordinaram e deixaram de cumprir o preceito básico acordados com as elites administrativas, que era o de manutenção da ordem entre seus subalternos de cor. Esses governadoras/dos das nações embora entendendo que haviam conquistado um lugar na engrenagem burocrática, como intermediários, não se dobraram completamente a obedecer aos desígnios das autoridades reinóis ou apenas não conseguiam manter sua autoridade entre seus subordinadas/dos.

Assim, entendemos que, apesar das patentes darem uma possibilidade de inserção e ascensão social aos negros e negras que as possuíam; e que possibilitavam manobras, ora para o lado do poder instituído, ora para os desfavorecidos, a dita Patente

\footnotetext{
8 Governadores e governadoras das nações formaram uma elite negra nas Irmandades do Rosário existentes em Pernambuco que controlavam e organizavam o trabalho de seus irmão de devoção e de cor.
}

Revista da ABPN • v. 12, n. Ed. Especial - Caderno Temático: "Africanos, escravizados, libertos biografias, imagens e experiências atlânticas” • agosto de 2020, p. $52-70$ 
foi um instrumento frágil para exercitar o domínio. A esse equilibrar, entre os poderes de uma elite branca e outra de cor, mesclavam-se as tensões cotidianas que envolviam jogos de afetividade e sexualidade, estratégias de sobrevivência e tudo o mais que está para além do cotidiano humano, transformando-o em um espaço aonde os lugares e as decisões são sempre provisórios.

\section{REFERÊNCIAS BIBLIOGRÁFICAS}

ALMEIDA, Suely Creusa Cordeiro de; SILVA, Giselda Brito. Ordem \& Polícia: controle político - social e formas de resistência em Pernambuco nos séculos XVIII ao XX. Recife: Editora Universitária/UFRPE, 2007.

O Sexo Devoto: normatização e resistência feminina no Império Português. Recife: Editora Universitária/UFPE, 2005.

O Feminino ao Leste do Atlântico: vendedeiras, regateiras, peixeiras e quitandeiras: mulheres e trabalho nas ruas de Lisboa e Luanda. In: GUEDES, Roberto (Org.) África: Brasileiros e Portugueses séculos XVI-XIX. Rio de Janeiro: Mauad X, 2013.

ARAÚJO. Clara Maria Farias de. Governadores das Nações e Corporações: cultura política e hierarquias de cor em Pernambuco (1776-1817). Dissertação (Mestrado em História) Rio de Janeiro: Universidade Federal Fluminense, 2007.

CARVALHO, Marcus J. M. de. Liberdade: rotinas e rupturas do escravismo no Recife, 18221850. Recife : Editora Universitária da UFPE, 2002.

COSTA, Valéria Gomes. Entre a África e o Recife:interpretação do Culto Chambá. Revista da ABPN, v.1, n.3-Nov.2010-fev.2011, p.157-180.

ELIAS, Norbert. Sociedade de Corte. Rio de Janeiro: Zahar, 2001.

GOMES, Fávio. História, Historiadores: ensino e pesquisa em História da Escravidão e da Pós- Emancipação. Revista da ABPN, v.8, n.18-Nov.2015-fev.2016, p.296-315.

HESPANHA, Antonio Manuel e XAVIER, Ângela Barreto. A representação da sociedade e do poder. In: HESPANHA, António Manuel (Org). História de Portugal. v. 4: O Antigo Regime. Lisboa: Ed. Estampa, 1993.

HESPANHA, António Manuel. Imbecillitas: as bem-aventuranças da inferioridade nas sociedades do Antigo Regime. Capes/Escola de Altos Estudos, PGH/UFMG: São Paulo: Annablume, 2010.

FIGUEIREDO, Luciano R. O Avesso da Memória. Cotidiano e trabalho da mulher em Minas Gerais no Século XVIII. Brasília: EDUMB; Rio de Janeiro: José Olympio, 1993.

Revista da ABPN • v. 12, n. Ed. Especial - Caderno Temático: "Africanos, escravizados, libertos biografias, imagens e experiências atlânticas” • agosto de 2020, p. $52-70$ 
PAIVA, E. F. Por meu trabalho, serviço e indústria: histórias de africanos, crioulos e mestiços na Colônia-Minas Gerais, 1717-1789. Tese (Doutorado em História). São Paulo:USP, 1999.

RIBEIRO Jr. José. Colonização e Monopólio no Nordeste brasileiro. São Paulo: Hicitec, 2004.

RUSSEL-WOOD, A.J.R. Escravos e Libertos no Brasil Colonial. Rio de Janeiro: Civlilização Brasileira, 2005.

RUSSEL-WOOD, Centros e periferias no mundo Luso - Brasileiro, 1500 - 1808. Revista Brasileira de História. V.18, n. 36, São Paulo, 1998.

Fontes primárias impressas

COSTA, F. A. Pereira da. Vocabulário Pernambucano. Recife: Secretaria de Cultura, 1976.

COSTA, Francisco Pereira da. Anais Pernambucanos. Recife: Secretaria de Cultura da Cidade do Recife, v. 6, 1985.

KOSTER, Henry. Viagens ao Nordeste do Brasil.2. ed. Prefácio e tradução de Luís da Câmara Cascudo. Recife: SEC; Departamento de Cultura. 1978. Ordenações Filipinas, Livro IV e V. Lisboa: Fundação Calouste Gulbenkian, 1985.

ROSARIO, Antônio do. Frutas do Brasil numa nova e ascética Monarchia, consagrada à Santíssima Senhora do Rosário. Lisboa: Biblioteca Nacional de Portugal, 2002.

TOLLENARE, L. F. Notas Dominicais. Recife: SEC. Departamento de Cultura, 1978.

VIDE, Sebastião Monteiro da. Constituições primeiras do Arcebispado da Bahia / feitas, e ordenadas pelo ilustríssimo e reverendíssimo D. Sebastião Monteiro da Vide. Brasília: Senado Federal, 2007.

VILHENA, Luis dos Santos. Recopilação de notícias soteropolitanas e brasílicas, contidas em XX cartas, que da cidade de Salvador Bahia de Todos os Santos escreve um a outro amigo em Lisboa. 2 v., Salvador, 1922.

Fontes primárias manuscritas

AHU- Avulsos de Pernambuco, Cx. 90, Doc. 7232; Cx.82, Doc. 6867; Cx.95. Doc. 7570; Cx. 99, Doc. 7757; Cx.97, Doc. 7622;

APEJE- Registros e Provisões - Bando (03.01.1769 -1797). Proibição das pessoas venderem fazendas pelas ruas.

APEJE- Patentes Provinciais v. 06 e 11 - Boceteiras e Comerciante; Pombeiras e Fora de Portas. 1788, 1789, 1802. p. 75, 263 e 267. Agradecemos a Hildo Rosas, do APEJE, pela localização e cessão das Patentes Negras.

APEJE- Patentes Provinciais - Cód. III, folha 92, 20.02.1778.

Revista da ABPN • v. 12, n. Ed. Especial - Caderno Temático: "Africanos, escravizados, libertos biografias, imagens e experiências atlânticas” • agosto de 2020, p. $52-70$ 
IAHGP- Livro de Registro da Câmara Municipal do Recife 1733-1808. p. 200v/201-203 - Carta do Sennado ao Rei sobre as negras venderem fazendas pellas ruas e o mais que nella se declara. Agradecemos ao Dr. George Félix Cabral pela cessão transcrita dessa documentação.

IAHGP - Testamento de Tereza Afonso/ Preta Forra 1768.

IAHGP- Câmara de Santo Antônio do Recife/Livro de Vereação (1764-1784, fls. 145 v e 146)/ 03/06/1773.

IAHGP- Câmara de Santo Antônio do Recife/Livro de Vereação (1785-1806, fls. 46) / 21/09/1788.

Recebido 05/07/2020

Aprovado em 22/07/2020

Revista da ABPN • v. 12, n. Ed. Especial - Caderno Temático: "Africanos, escravizados, libertos biografias, imagens e experiências atlânticas" • agosto de 2020 , p. $52-70$ 